Artikel Penelitian

\title{
PENGEMBANGAN MEDIA PEMBELAJARAN KALENDER SEJARAH (KASA) BERMUATAN WAWASAN KEBANGSAAN POKOK BAHASAN PERGERAKAN NASIONAL INDONESIA
}

\author{
Miftakhul Khassanah \\ miftakhulkhassanah@gmail.com \\ SMAN 1 Cepu, Blora
}

\begin{abstract}
However, the reality shows that the learners experienced problems understanding the aspects of time, events, facts and interpret events. In addition, students also experienced the problem of knowing the nationality concept. One of the solutions to this problem is generating and testing the effectiveness of learning media namely Calendar History (Kasa) that contain the nationality concept on a subject matter of the national movement of Indonesia. The results showed the effective history of Calendar in a rational and field test.
\end{abstract}

Key words: Historical instruction media, Calendar History, the nationality concept

\section{PENDAHULUAN}

Pembelajaran sejarah yang ideal menekankan pentingnya pemaknaan terhadap peristiwa tanpa melupakan aspek waktu dan fakta peristiwa. Selain itu, pembelajaran sejarah juga menekankan pentingnya penanaman wawasan kebangsaan (Ali, 2005:351). Namun kenyataan di lapangan menunjukkan peserta didik mengalami permasalahan memahami aspek waktu, fakta, dan memaknai peristiwa. Selain itu peserta didik juga mengalami permasalahan pengetahuan wawasan kebangsaan.

Kalender memiliki potensi untuk dikembangkan menjadi media pembelajaran sejarah yang mampu menginformasikan aspek waktu, fakta peristiwa, dan makna peristiwa sejarah. Upaya yang dilakukan adalah menciptakan dan menguji efektifitas produk media pembelajaran Kalender Sejarah (Kasa) bermuatan wawasan kebangsaan pokok bahasan Pergerakan Nasional Indonesia. Nilai yang dimuat dalam media Kalender Sejarah adalah wawasan kebangsaan sebagai salah satu upaya mengatasi permasalahan wawasan kebangsaan peserta didik.

Kalender Sejarah merupakan salah satu upaya inovasi pengembangan media pembelajaran sejarah. Pentingnya pengembangan media Kalender Sejarah ini sebagaimana pendapat Soewarso (2000:102) yang menyatakan bahwa media bervariasi mutlak diperlukan dalam pengajaran sejarah. Hal ini sebagaimana pendapat Widja 
(1989:1) yang menyatakan kurangnya inovasi dalam penggunaan media pembelajaran dapat menyebabkan minat peserta didik kurang terhadap pembelajaran sejarah.

Media pembelajaran secara umum diartikan sebagai segala sesuatu yang dapat digunakan untuk menyampaikan informasi kepada peserta didik maupun untuk merangsang pikiran, perasaan, minat, perhatian dan kemauan dalam proses belajar baik secara pengajaran di kelas maupun pembelajaran secara mandiri (Hamalik, 1989:16; Setyosari \& Sihkabuden, 2005:17; Winkel, 2005:318; Sadiman, 2008;17). Sedangkan pengertian media pembelajaran dalam pengajaran sejarah meliputi bukan saja benda-benda atau dokumen peninggalan sejarah ataupun orang-orang sebagai pelaku sejarah yang merupakan jejak atau sumber langsung serta konkrit dari suatu peristiwa sejarah, tetapi juga hal-hal lain yang bisa membantu dan memudahkan murid memvisualisasikan suatu peristiwa (Widja, 1989:60-61).

Landasan teori pengembangan media Kalender Sejarah merujuk pada Kochar (2008:404), yang mengatakan "ketika para siswa mencapai tahap sekunder yang lebih tinggi, ia harus dapat menggunakan kalender, mengingat tanggal peristiwa dengan menggunakan ungkapan waktu yang pasti dan tidak pasti...". Selain itu, Kalender juga berpotensi dikembangkan menjadi media pembelajaran sejarah yang dapat memuat waktu, fakta peristiwa dan makna peristiwa sejarah. Namun pembelajaran sejarah kebanyakan tidak pernah mengembangkan maupun menggunakan kalender sebagai media pembelajaran.

Materi yang dikembangkangkan pada media Kalender Sejarah adalah Pergerakan Nasional Indonesia. Alasan pemilihan materi tersebut secara teoritis sebagaimana pendapat Tim Penyusun (1999:12), bahwa peristiwa 20 Mei 1908 dan 28 Oktober 1928 merupakan bentuk wawasan dan semangat kebangsangsaan yang paling ampuh dan totalitas serta berpotensi untuk mengajarkan wawasan kebangsaan. Selain itu Hamid \& Madjid (2011:136) juga berpendapat "awal lahirnya kesadaran nasional merupakan fase penting dalam Sejarah Indonesia yang sering dikaitkan dengan berdirinya Budi Utomo (BU) pada 20 Mei 1908". Sedangkan secara empirik dikembangkan berdasarkan pertimbangan kebutuhan guru dan peserta didik di SMK Negeri 1 Kepanjen.

\section{METODE}

Penelitian ini dilakukan dengan metode penelitian dan pengembangan atau sering disebut Research and Development ( $R \& D$ ). Metode penelitian pengembangan menurut Sugiyono (2015:407) adalah metode penelitian yang digunakan untuk menghasilkan produk tertentu, dan menguji efektivitas produk tersebut. Model pengembangan dalam 
penelitian ini adalah model prosedural. Prosedur atau langkah-langkah penelitian pengembangan mengolah dari siklus R \& D Sugiyono (2015:409) yang terdiri dari 10 langkah. Langkah-langkah penelitian adalah potensi dan masalah, pengumpulan data, desain produk, validasi desain, revisi desain, uji coba produk, revisi produk, uji coba pemakaian, revisi produk, dan produksi akhir.

Penelitian dilakukan di SMK Negeri 1 Kepanjen, Kabupaten Malang. Subjek uji coba dalam penelitian ini adalah kelas $X$ dari berbagai jurusan yang diharapkan dapat mewakili seluruh karakteristik siswa SMK Negeri 1 Kepanjen. Subjek uji coba kelompok kecil dilakukan pada 30 peserta didik yang diambil dengan cara mengambil 6 siswa kelas $X$ dari setiap jurusan yang ada di SMKN 1 Kepanjen secara random. Sedangkan subjek coba pada uji coba kelompok besar adalah seluruh siswa dari masing-masing satu kelas setiap jurusan. Kelas yang dijadikan subjek coba dalam uji coba kelompok besar yaitu kelas X RPL 2, X TSM 2, X TEI 2, X TKR 2, dan X TKJ 2.

Instrumen pengumpulan data yang digunakan dalam penelitian dan pengembangan ini adalah angket dan tes. Angket digunakan sebagai instrumen pengumpulan data untuk mengetahui penilaian validator dan subjek coba terhadap produk media Kalender Sejarah. Sedangkan instrumen tes untuk memastikan efektivitas media Kalender Sejarah dalam konteks materi tentang pengetahuan wawasan kebangsaan pada materi Pergerakan Nasional Indonesia. Tes dilakukan dengan memberikan pre-test dan post-test untuk mengetahui perbandingan pengetahuan sebelum dan sesudah penggunaan media Kalender Sejarah tentang pengetahuan wawasan kebangsaan materi Pergerakan Nasional Indonesia.

\section{HASIL PENELITIAN DAN PEMBAHASAN}

Produk penelitian dan pengembangan berupa media Kalender Sejarah. Kontenkonten yang terdapat dalam media Kalender Sejarah meliputi konten lembar kalender, seputar materi, kotak kronologi, dan buku deskripsi peristiwa sejarah. Produk pengembangan juga dilengkapi dengan buku petunjuk penggunaan. Gambar 1 merupakan tampilan media Kalender Sejarah (KASA). 


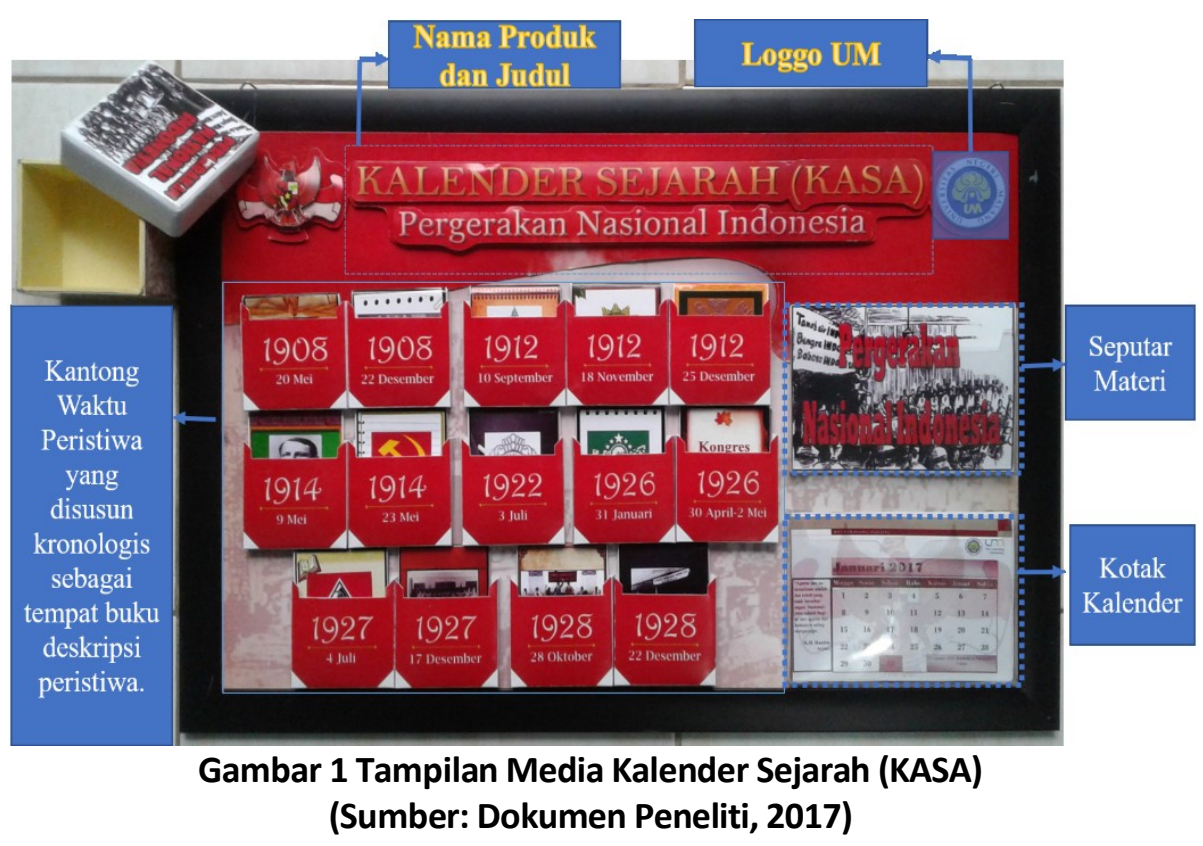

Hasil penelitian menunjukkan media Kalender Sejarah efektif secara rasional maupun uji lapangan. Konteks materi dalam media Kalender Sejarah juga menunjukkan efektif meningkatkan pengetahuan tentang wawasan kebangsaan pada pokok bahasan Pergerakan Nasional Indonesia sebesar 43,40. Efektifitas media Kalender Sejarah secara rasional ditunjukkan dengan hasil validasi. Hasil validasi ahli materi dosen sejarah, ahli materi guru sejarah dan ahli media dosen sejarah terhadap media Kalender Sejarah menunjukkan bahwa media Kalender Sejarah yang dikembangkan valid tanpa direvisi. Hasil vaidasi adalah sebagai berikut: rata-rata persentasi ahli materi dosen sejarah sebesar $94,44 \%$, rata-rata persentase ahli materi guru sejarah sebesar $97,22 \%$ dan ratarata persentase ahli media dosen sejarah sebesar $81,94 \%$. Berdasarkan penilaian tersebut maka dapat disimpulkan bahwa media pembelajaran sejarah yang dikembangkan oleh peneliti sudah valid dan dapat digunakan dalam tahap uji coba tanpa perlu dilakukan revisi.

Meskipun dalam kategori valid tanpa revisi, namun terdapat beberapa komentar dan saran terhadap pengembangan media Kalender Sejarah. Komentar dan saran digunakan sebagai bahan pertimbangan untuk merevisi produk. Berikut akan disajikan revisi produk berdasarkan komentar dan saran validator. 


\section{Revisi Produk Ahli Materi Dosen Sejarah}

Mengganti kata "produk" dengan "nilai-nilai pendidikan" pada pembahasan organisasi Taman Siswa. Kata "nilai-nilai pendidikan" lebih sesuai jika dibandingkan dengan kata "produk" untuk pembahasan organisasi Taman Siswa yang berorientasi pendidikan. Gambar 2 merupakan tampilan refleksi Taman Siswa produk awal, sedangkan gambar 3 merupakan tampilan refleksi Taman Siswa hasil revisi.

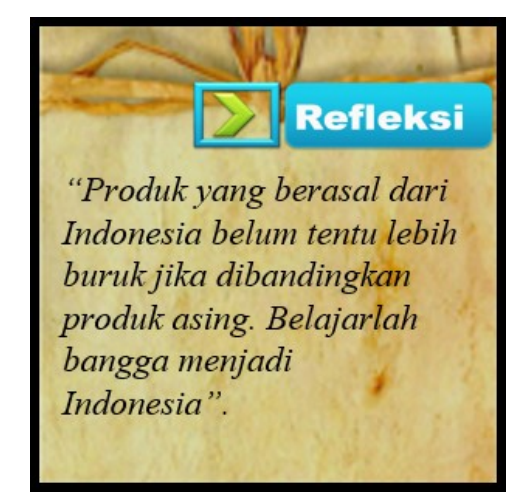

Gambar 2 Tampilan Refleksi Taman Siswa Produk Awal

(Sumber: Dokumen Peneliti, 2017)

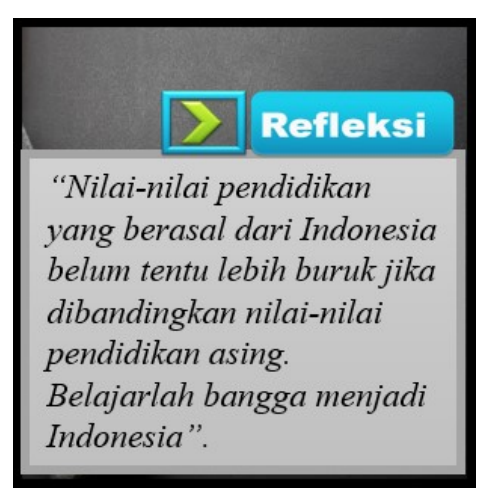

Gambar 3 Tampilan Refleksi Taman Siswa Hasil Revisi

(Sumber: Dokumen Peneliti, 2017)

Revisi lain yang dilakukan yaitu kata Quote dipilih untuk menjadi identitas quote dari tokoh yang bersangkutan. Gambar 4 merupakan tampilan quote Budi Utomo produk awal, sedangkan gambar 5 merupakan tampilan quote Budi Utomo hasil revisi.

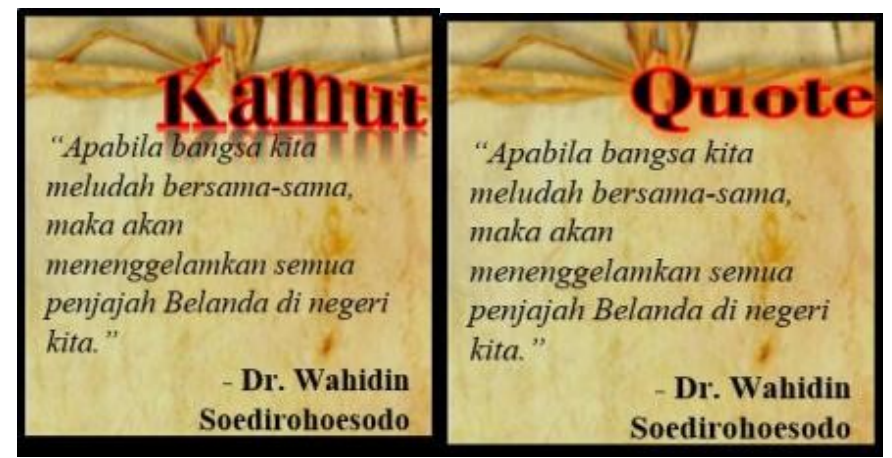

Gambar 4 Tampilan Quote Budi

Utomo Produk Awal

(Sumber: Dokumen Peneliti, 2017)

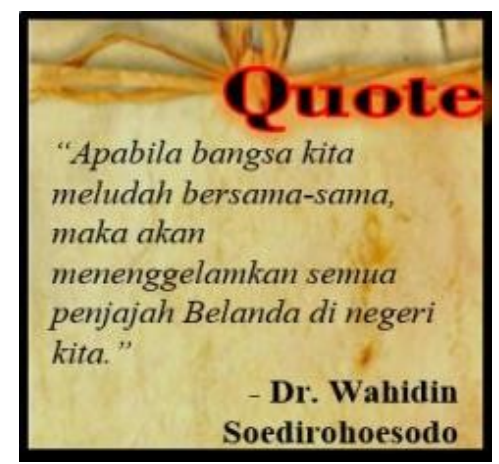

Gambar 5 Tampilan Quote Budi Utomo Hasil Revisi

(Sumber: Dokumen Peneliti, 2017) 
Pada revisi materi dilakukan dengan menambah PNI Baru atau PNI Pendidikan dalam materi organisasi PNI. Dilakukan revisi karena materi organisasi PNI pada produk awal hanya menyebutkan PNI Baru tanpa menjelaskanya. Oleh sebab itu pada revisi produk ditambahkan penjelasan tentang PNI Baru atau PNI Pendidikan. Gambar 6 merupakan tampilan penambahan materi PNI Baru.
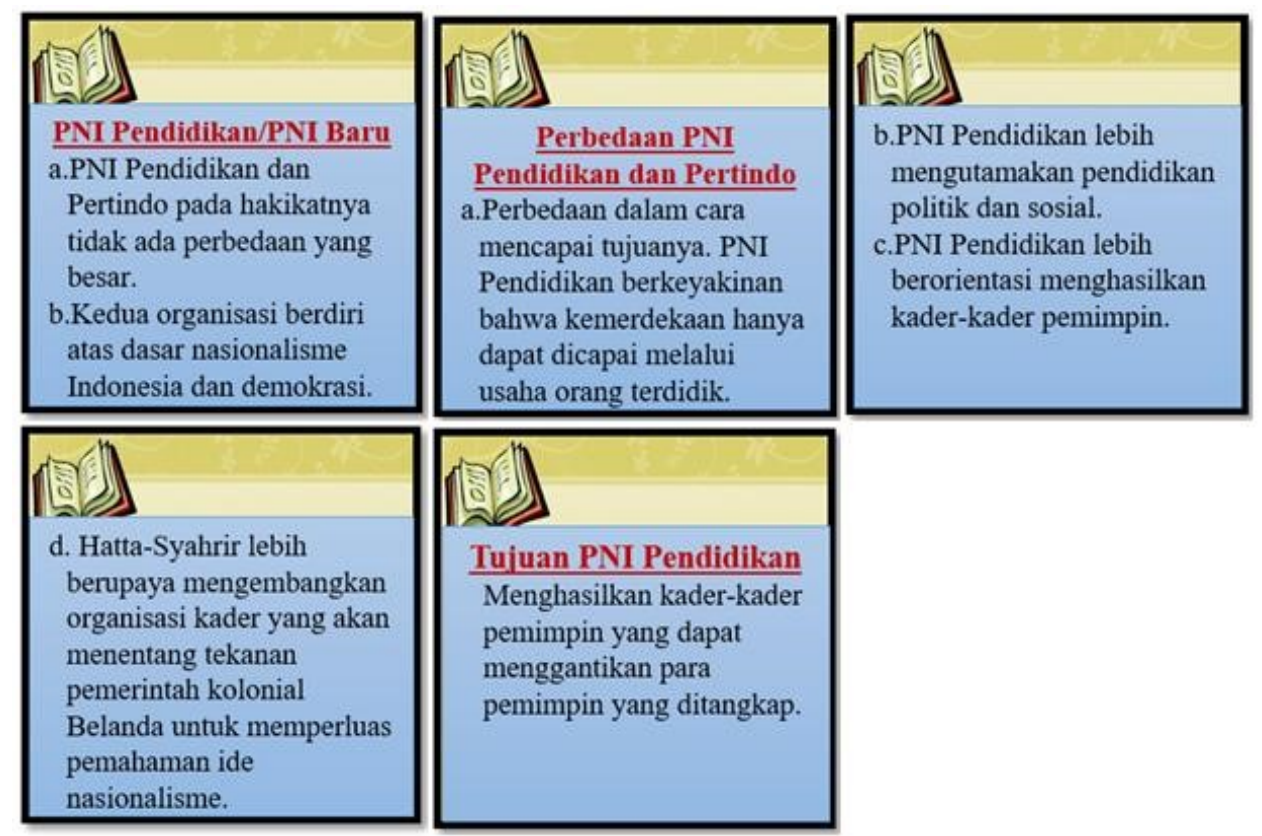

\section{Gambar 6 Tampilan Materi PNI Baru atau PNI Pendidikan (Sumber: Dokumen Peneliti, 2017)}

Selain itu perbaikan juga dilakukan pada materi ISDV. Pada awalnya organisasi ISDV kurang refleksi dan quote, akhirnya materi dilengkapi dengan refleksi dan quote. Gambar 7 merupakan tampilan penambahan refleksi dan quote organisasi ISDV.
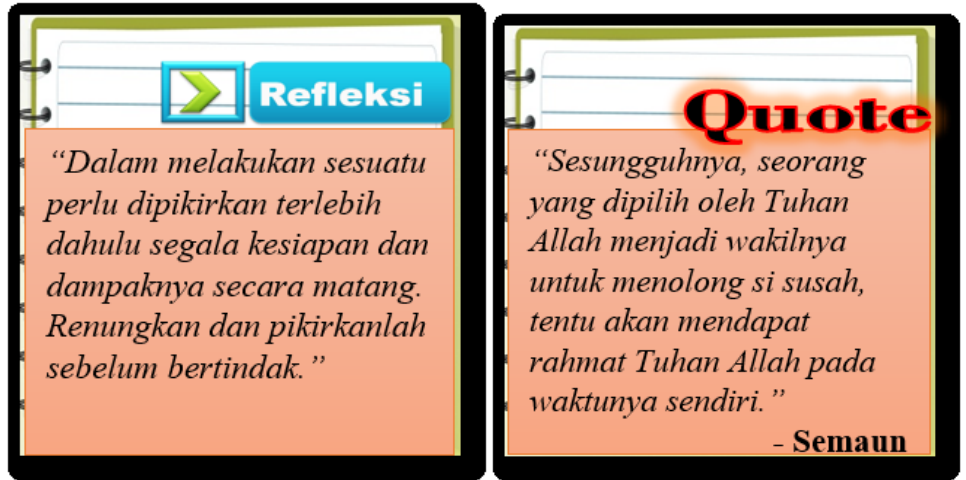

Gambar 7 Tampilan Refleksi dan Quote Organisasi ISDV

(Sumber: Dokumen Peneliti, 2017) 
Berdasarkan saran ahli materi, perbaikan dilakukan dengan menambah faktor kemunduran Sarekat Islam (SI) dengan faktor sebagian besar anggota Sarekat Islam masuk Partai Komunis Indonesia. Pada awalnya faktor kemunduran SI hanya berjumlah 3, yaitu pengaruh ISDV, perbedaan pendapat H.O.S Tjokroaminoto dengan Semaun, dan perbedaan pendapat antara Sukiman-Surjopranoto dengan Tjokroaminoto-H.A Salim. Berdasarkan saran ahli materi maka faktor kemunduran ditambah dengan sebagian besar anggota SI masuk PKI. Gambar 8 merupakan tampilan penambahan faktor kemunduran Sarekat Islam.

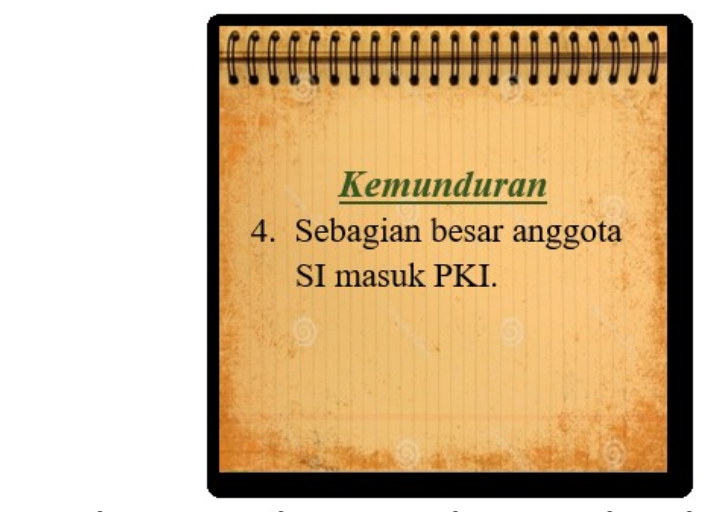

Gambar 8 Tampilan Kemunduran Sarekat Islam Hasil Revisi

(Sumber: Dokumen Peneliti, 2017)

Selain itu juga menambahkan gambar R.A. Kartini dalam materi Kongres Perempuan I. Pada awalnya hanya disebutkan nama R.A Kartini. Kemudian berdasarkan saran ahli materi maka ditambahkan foto R.A Kartini. Gambar 9 merupakan tampilan gambar R.A. Kartini.

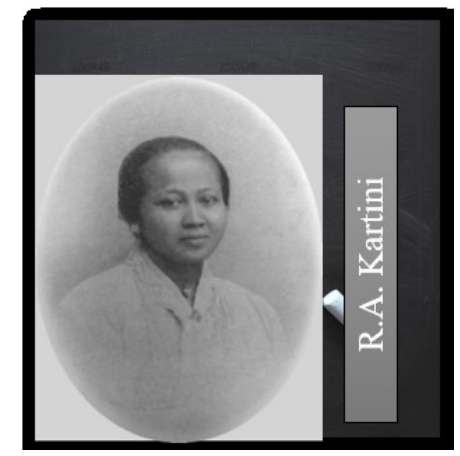

Gambar 9 Tampilan Gambar R.A. Kartini

(Sumber: Abdullah \& Lapian, 2012:367)

\section{Revisi Produk Ahli Materi Guru Sejarah}

Hasil revisi perlu membandingkan beberapa versi untuk keakuratan materi. Materi dalam Kalender Sejarah diteliti kembali dengan membandingkan beberapa sumber sebagai acuan dalam keakuratan materi. Berbagai sumber tersebut dapat dilihat dalam 
daftar buku-buku yang digunakan dalam mengembangkan media Kalender Sejarah ini. Gambar 10 merupakan tampilan daftar buku-buku yang digunakan dalam pengambangan media Kalender Sejarah.

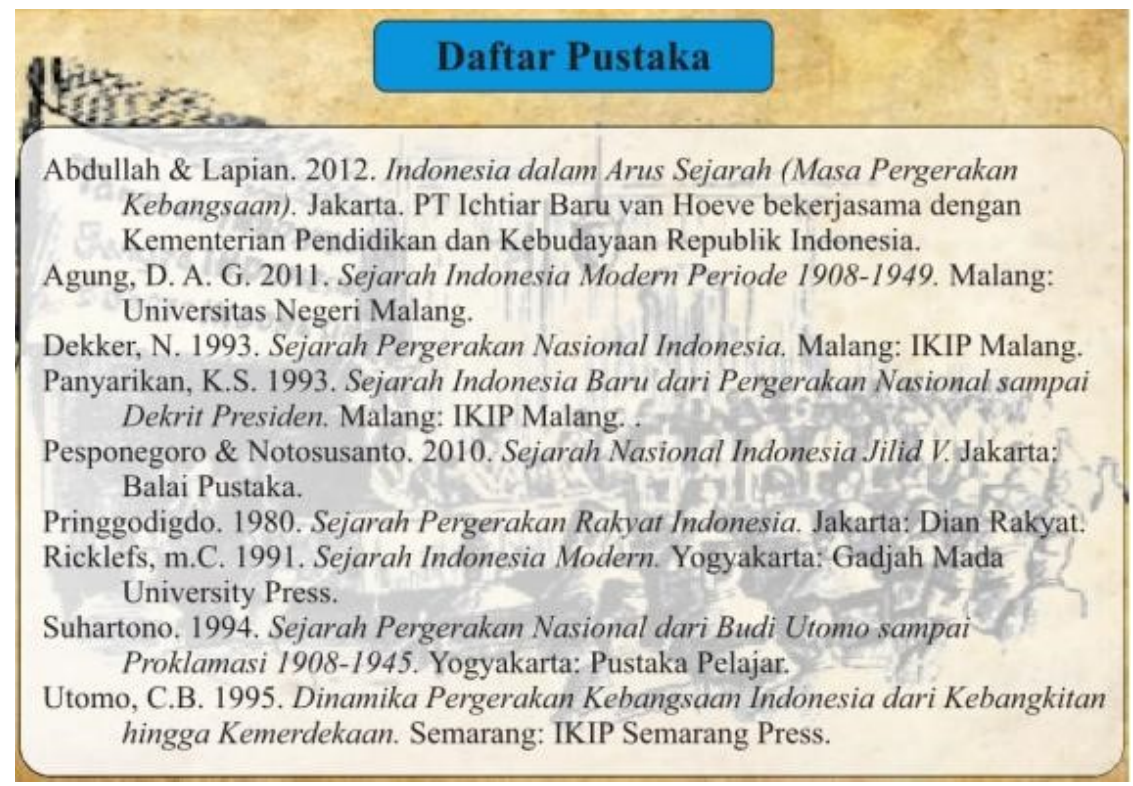

\section{Gambar 10 Tampilan Daftar Buku-Buku yang Digunakan Media Kalender Sejarah (Sumber: Dokumen Peneliti, 2017)}

Pada Nilai-nilai untuk meningkatkan wawasan kebangsan perlu dimasukkan lebih banyak lagi di dalam materi. Nilai-nilai yang ditambahkan untuk meningkatkan wawasan kebangsaan dapat dilihat dalam gambar 11.

Pedoman Perjuangan
Orang tua dan pemuda
memang memiliki karakter
yang berbeda. Namun
perbedaan tidak seharusnya
berakhir dengan
perpecahan, melainkan
dapat saling melengkapi.

\begin{tabular}{|c|c|}
\hline 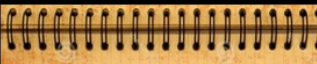 & $(2)=$ \\
\hline Defleksi & "Kemajemukan, \\
\hline $\begin{array}{l}\text { Dalam menjalin } \\
\text { organisasi, hal yang utama } \\
\text { adalah persatuan. Karena } \\
\text { dengan persatuan sesuatu } \\
\text { akan mudah dikerjakan } \\
\text { untuk mencapai tujuan. }\end{array}$ & $\begin{array}{l}\text { keanekaragaman tetap ada } \\
\text { dan dihormati, tetapi } \\
\text { semangat perjuangan dan } \\
\text { pengakuan bertanah air, } \\
\text { berbangsa, dan berbahasa } \\
\text { satu yakni Indonesia telah } \\
\text { bulat." }\end{array}$ \\
\hline
\end{tabular}

\section{Gambar 11 Tampilan Nilai-Nilai Wawasan Kebangsaan yang Ditambahkan (Sumber: Dokumen Peneliti, 2017)}




\section{Revisi Produk Ahli Media}

Berdasarkan masukan ahli media perlu dilengkapi dengan buku petunjuk. Buku petunjuk terdiri dari dua buku yaitu buku guru dan buku siswa. Hal yang terkandung dalam buku meliputi seputar Kalender Sejarah, konten-konten dalam Kalender Sejarah, petunjuk penggunaan Kalender Sejarah dalam pembelajaran, evaluasi, dan penggunaan Kalender Sejarah untuk sehari-hari. Gambar 12 merupakan tampilan buku petunjuk media Kalender Sejarah.

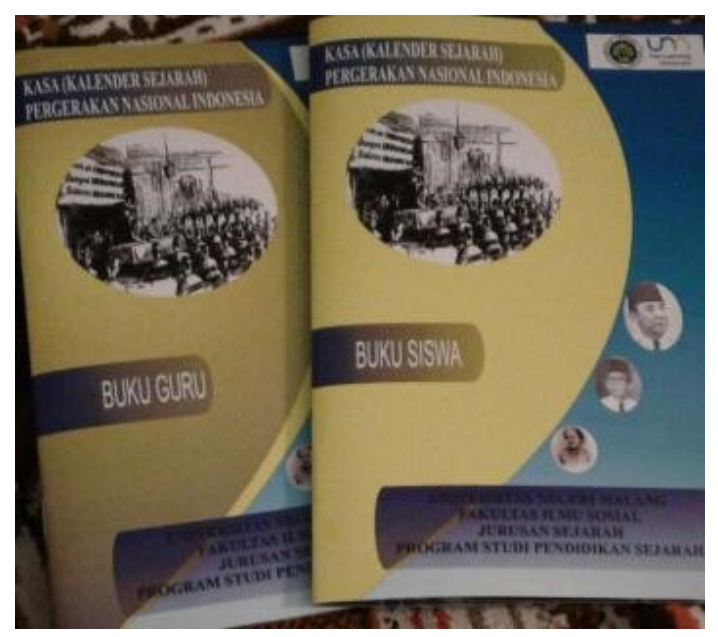

Gambar 12 Buku Petunjuk Media Kalender Sejarah

(Sumber: Dokumen Peneliti, 2017)

Background tiap organisasi akan lebih menarik jika dibedakan. Background deskripsi materi yang awalnya sama kemudian dibuat berbeda tiap deskripsi. Gambar 13 merupakan tampilan backgroud produk awal, sedangkan 14 merupakan tampilan background hasil revisi.

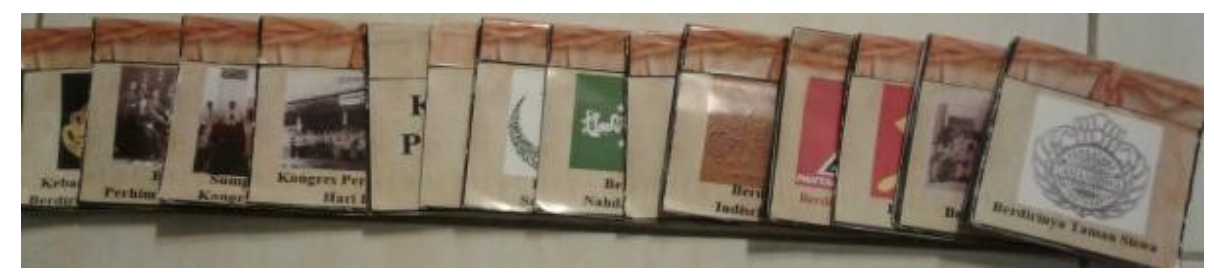

Gambar 13 Tampilan Background Produk Awal

(Sumber: Dokumen Peneliti, 2017)

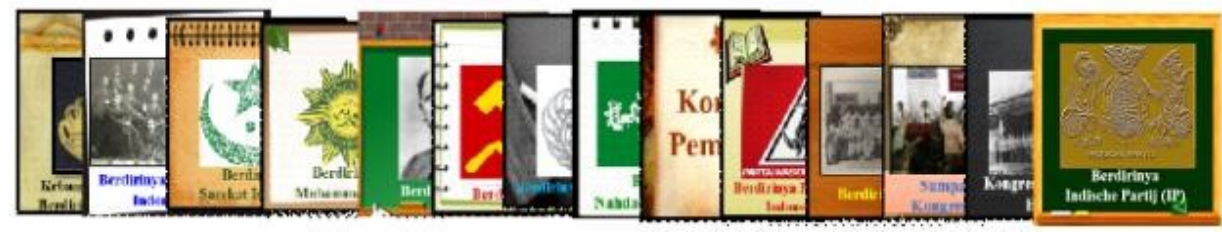

Gambar 14 Tampilan Background Hasil Revisi

(Sumber: Dokumen Peneliti, 2017) 
Pada Sub-sub bagian penting seperti "tujuan", "upaya" dibuat warna beda sehingga terkesan subbagian yang penting. Gambar 15 merupakan contoh tampilan subbagian hasil revisi.

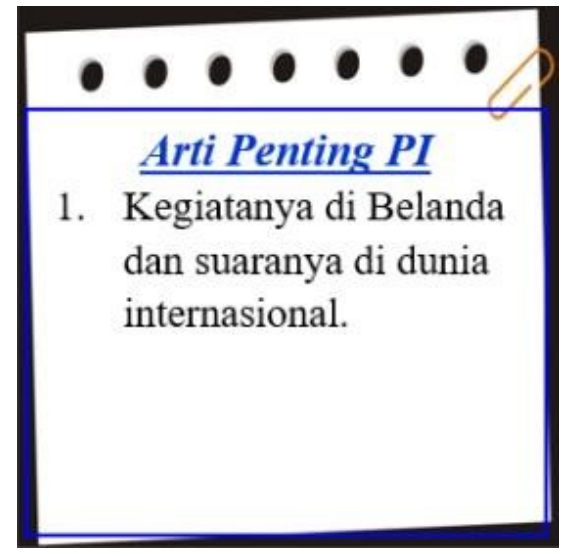

Gambar 15 Tampilan Contoh SubBagian Hasil Revisi

(Sumber: Dokumen Peneliti, 2017)

Pada tulisan judul dibuat warna yang cerah. Tulisan judul media diperbaiki dengan menggunakan warna yang lebih cerah. Gambar 16 merupakan tampilan judul produk awal, sedangkan 17 merupakan tampilan judul hasil revisi.

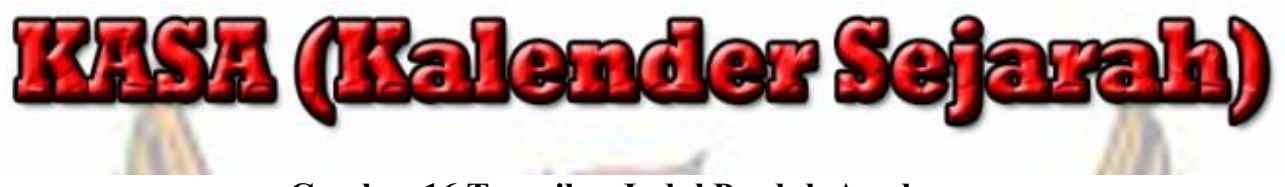

Gambar 16 Tampilan Judul Produk Awal

(Sumber: Dokumen Peneliti, 2017)

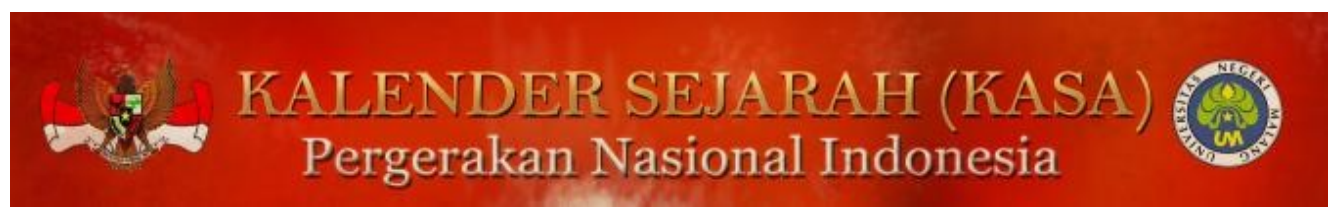

Gambar 17 Tampilan Judul Hasil Revisi

(Sumber: Dokumen Peneliti, 2017)

Hasil respon peserta didik pada uji coba kelompok kecil dan uji coba kelompok besar menunjukkan bahwa media Kalender Sejarah efektif secara lapangan. Rata-rata persentase pada uji coba kelompok kecil sebesar $87 \%$ dan pada uji coba kelompok besar sebesar $88 \%$. Namun terdapat beberapa komentar dan saran terhadap media Kalender Sejarah. Komentar dan saran digunakan sebagai bahan pertimbangan untuk merevisi produk. Berikut akan disajikan revisi produk berdasarkan hasil uji coba. 


\section{Revisi Produk Hasil Uji Coba Kelompok Kecil}

Revisi yang dilakukan adalah gambar yang disajikan dalam media Kalender Sejarah disesuaikan dengan keadaan yang sebenarnya. Hal ini dilakukan untuk merevisi gambar pada organisasi Sumpah Pemuda. Gambar 18 merupakan tampilan cover Sumpah Pemuda produk awal dan gambar 19 merupakan tampilan cover Sumpah Pemuda hasil revisi.

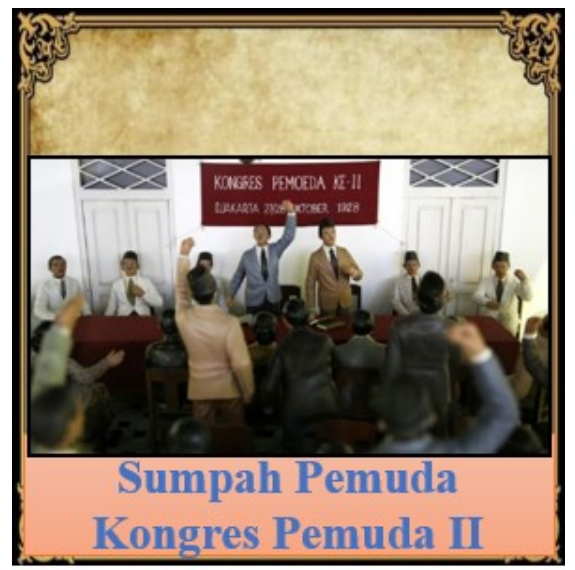

Gambar 18 Tampilan Cover Sumpah Pemuda Produk Awal

(Sumber: Dokumen Peneliti, 2017)

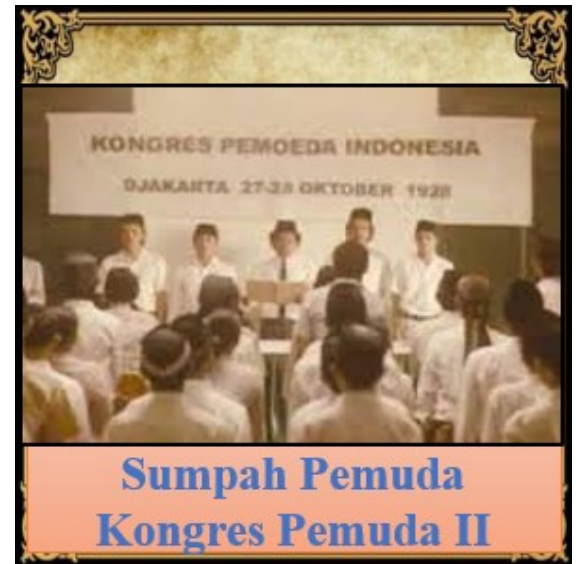

Gambar 19 Tampilan Cover Sumpah Pemuda Hasil Revisi

(Sumber: Dokumen Peneliti, 2017)

\section{Revisi Produk Uji Coba Kelompok Besar}

Revisi dilakukan terhadap lembar bulan Mei, yang terdapat kesalahan ketik pada tahun berdirinya organisasi PKI. Gambar 20 merupakan tampilan bulan Mei produk awal dan gambar 21 merupakan tampilan bulan Mei hasil revisi.

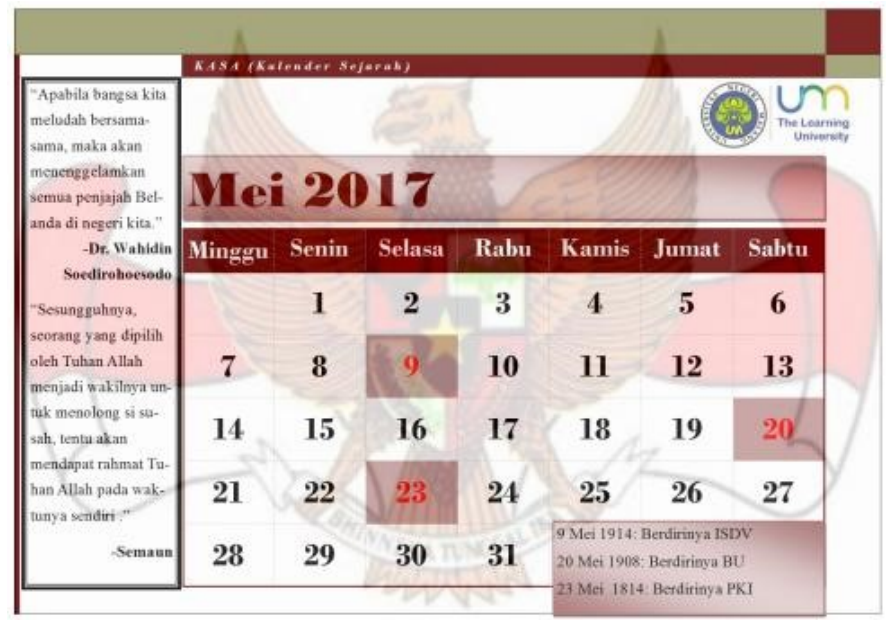

Gambar 20 Tampilan Bulan Mei Produk Awal

(Sumber: Dokumen Peneliti, 2017) 


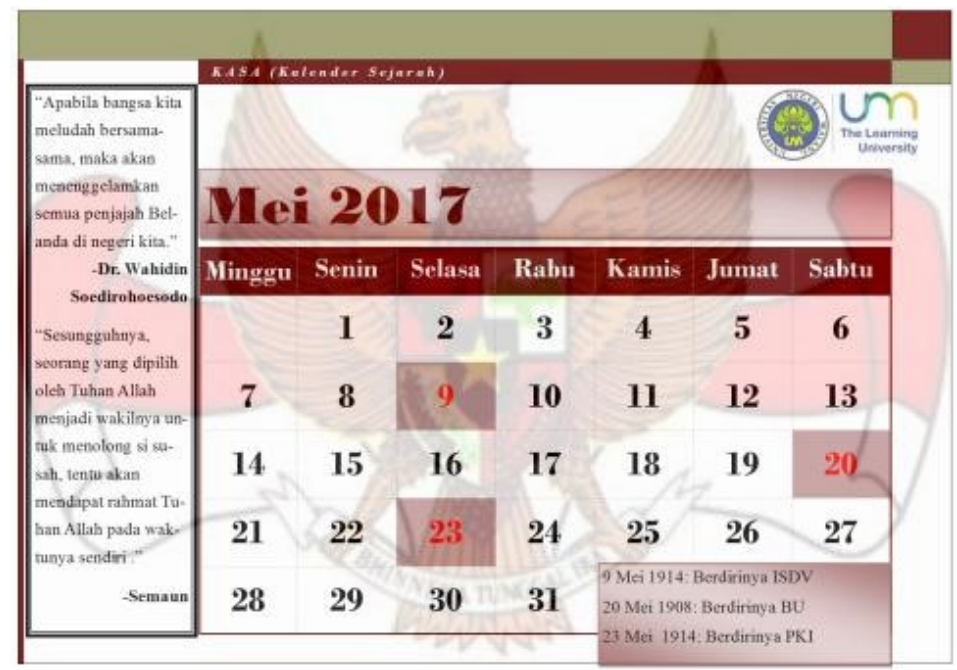

\section{Gambar 21 Tampilan Bulan Mei Hasil Revisi \\ (Sumber: Dokumen Peneliti, 2017)}

Selain hasil validasi dan angket respon peserta didik. Penelitian ini juga menggunakan pre-test dan post-test untuk memastikan efektifitas media Kalender Sejarah dalam konteks materi bermuatan wawasan kebangsaan pokok bahasan Pergerakan Nasional Indonesia. Adapun rekapitulasi hasil pre-test dan post-test dapat dilihat pada tabel 1 berikut:

Tabel 1: Rekapitulasi Hasil Pre-test dan Post-test Peserta Didik ( $\mathrm{n}=158$ )

\begin{tabular}{lllll}
\hline & Pre-test & \multicolumn{3}{l}{ Post-test } \\
\cline { 2 - 5 } & $\Sigma \mathrm{X}$ & $\Sigma \mathrm{Xi}$ & $\Sigma \mathrm{X}$ & $\Sigma \mathrm{Xi}$ \\
\hline Jumlah & 6288 & 15800 & 13146 & 15800 \\
\hline Rata-rata & 39,80 & 100,00 & 83,20 & 100,00 \\
\hline Persentase & $39,80 \%$ & $100,00 \%$ & $83,20 \%$ & $100,00 \%$ \\
\hline
\end{tabular}

(Sumber: Rekapitulasi Hasil Belajar Siswa)

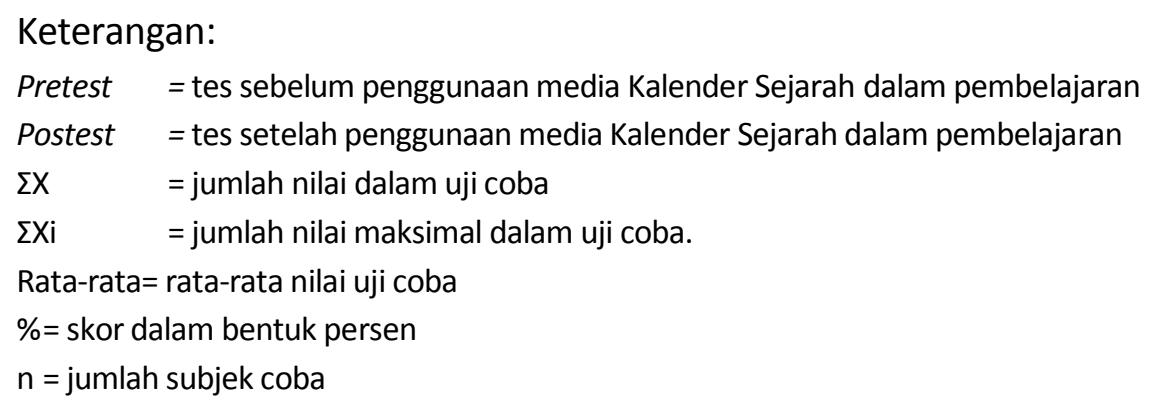

Berdasarkan paparan data rekapitulasi hasil pre-tets dan post-test pengetahuan wawasan kebangsaan pada tabel 1 di atas, maka dapat dilihat rata-rata hasil pre-test 
sebesar 39,80 dan rata-rata post-test sebesar 83,20 . Selisih rata-rata nilai pre-test dan post-test sebesar 43,40 . Hasil rata-rata tersebut memperkuat bahwa pengembangan media Kalender Sejarah efektif. Berikut sajian rata-rata hasil belajar pengetahuan wawasan kebangsaan siswa sebelum dan sesudah menggunakan media Kalender Sejarah pada gambar 22 dalam format gambar grafik:

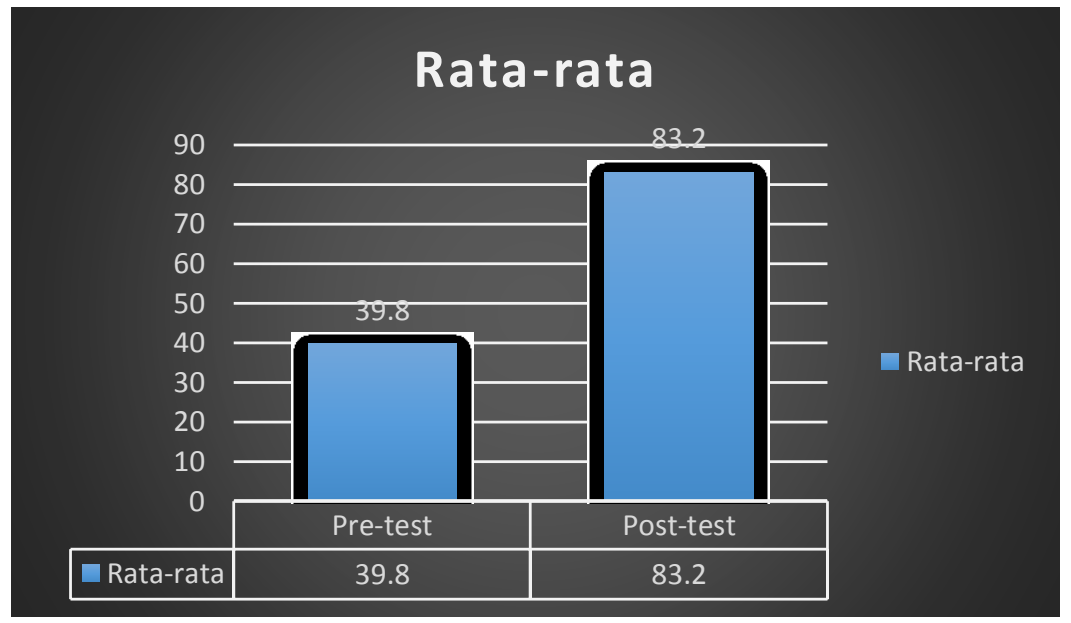

Gambar 22 Grafik Rata-Rata Hasil Belajar Siswa (Pre-test dan Post-test)

\section{SIMPULAN}

Pengembangan media Kalender Sejarah telah melalui uji validasi dan uji coba. Berdasarkan hasil validasi dan hasil uji coba, media Kalender Sejarah dinyatakan valid dan efektif secara rasional dan uji lapangan. Media Kalender Sejarah juga terbukti efektif untuk meningkatkan hasil belajar pengetahuan wawasan kebangsaan materi Pergerakan Nasional Indonesia.

Berdasarkan kesimpulan di atas, saran yang dirumuskan adalah sebagai berikut. Saran pemanfaatan produk, guru sejarah sebaiknya terlebih dahulu mempelajari petunjuk dan materi yang terkandung dalam Kalender Sejarah sebelum menerapkannya dalam pembelajaran di kelas. Saran diseminasi produk, Media Kalender Sejarah pokok bahasan Pergerakan Nasional Indonesia dapat digunakan untuk menunjang pembelajaran sejarah. Saran pengembangan lebih lanjut, agar pengembang lain dapat mengembangkan media Kalender Sejarah pada materi-materi lain dan dapat meningkatkan kreativitasnya dalam pembuatan media Kalender Sejarah. Selain itu media Kalender Sejarah juga dapat dikembangkan dalam bentuk aplikasi. 


\section{DAFTAR PUSTAKA}

Abdullah \& Lapian. 2012. Indonesia dalam Arus Sejarah (Masa Pergerakan Kebangsaan). Jakarta. PT Ichtiar Baru van Hoeve bekerjasama dengan Kementerian Pendidikan dan Kebudayaan Republik Indonesia.

Ali, M. 2005. Pengantar Ilmu Sejarah Indonesia. Yogyakarta: Lkis.

Hamalik, O. 1989. Media Pendidikan. Bandung: Citra Aditya.

Hamid, A. R. \& Madjid, M. S. 2011. Pengantar Ilmu Sejarah. Yogyakarta: Ombak.

Kochhar, S.K. 2008. Pembelajaran Sejarah (Teaching of History). Jakarta: Gramedia.

Sadiman, A. S. dkk. 2008. Media Pendidikan: Pengertian, Pengembangan dan Pemanfaatanya. Jakarta: Rajawali.

Setyosari, P \& Sihkabuden. 2005. Media Pembelajaran. Malang: Elang Mas.

Soewarso. 2000. Cara-Cara Penyampaian Pendidikan Sejarah untuk Membangkitkan Minat Peserta Didik Mempelajari Sejarah Bangsanya. Jakarta: Proyek Pengembangan Guru Sekolah Menengah IBRD Loan No. 3979. Dirjendikti Departemen Pendidikan Nasional.

Sugiyono. 2015. Metode Penelitian Pendidikan: Pendekatan Kuantitatif, Kualitatif, dan $R \& D$. Bandung: Alfabeta.

Tim Penyusun Buku Hubungan-Sipil Militer Lembaga Ketahanan Nasional Departemen Pertahanan Keamanan RI. 1999. Wawasan Kebangsaan Menuju Indonesia Baru. Jakarta: Gramedia Widiasarana Indonesia.

Widja, I Gde.1989. Dasar-Dasar Pengembangan Strategi serta Metode Pengajaran Sejarah. Jakarta: PPLPTK Dirjen Dikti Depdikbud.

Winkel, W.S. 2005. Psikologi Pengajaran. Yogyakarta: Media Abadi. 